\title{
Divisions, Intersections, and Demographics: Women's Human Rights and Reproductive Justice in India
}

\author{
Joshua D. Kepkay
}

\begin{abstract}
Tensions continue to endure between the right to cultural accommodation and women's human rights within multicultural states. This research examines a variety of secondary sources to compare the autonomy of Muslim women with Hindu women across India. Both are found to possess some autonomy in their lives and over their bodies, although areas of independence vary with each culture. Kinship model and geographic location are perhaps the most important indicators of the autonomy available to a woman in India with religion proving to be of only periphery importance once all variables are evaluated. In the pursuits of human rights, cultural identity presents the key difference between Muslim and Hindu women. It impacts both to whom they address their claims for gender justice and how they present those claims. Hindu women are better situated under federal legislation to exit from abusive marriages because their group is the majority. As such, the largely Hindu societal culture is more receptive to their claims. Muslim women, however, as part of a minority group, face cultural barriers that inhibit the state's accommodation of their human rights.
\end{abstract}

Key Terms: feminism, women's rights, reproductive rights, patriarchy, India, Muslim, Hindu, Shah Bano, Muslim Personal Law, kinship models, maternal health, multiculturalism

\section{Introduction}

Group mobilization, and state accommodation on the basis of culture, defines the nature of multicultural politics. To protect the legitimacy of their cultural claims under multiculturalism, dominant males seek to impose restrictions on the bodies of women within their cultural groups. This research seeks only to examine the autonomy of women in India. It asks if Muslim culture in India is more oppressive toward women than the majority Hindu culture. ${ }^{1}$ It argues that although Muslim religious doctrine explicitly restricts the availability of reproductive autonomy to women, Hindu practices can also be highly restrictive. As this research focuses on women's autonomy, multiculturalism, human rights, and the abortion

\footnotetext{
${ }^{1}$ For the purposes of this research, culture is understood as "a way of life" that includes religion, language, values, symbols, and orientations constructed through socialization. It is not seen as homogenous, but as important to those who advocate for recognition and accommodation (Li, 1999).
} 
debate-prolife versus prochoice, it provides a portrayal of multiculturalism in India through a feminist lens. The debate is contextualized within India because the applicability of the preexisting theories is too limited due to overgeneralization ${ }^{2}$ or because the focus only concerns western liberal democracies. ${ }^{3}$ Women's sexual autonomy is examined as an indicator of the respective gender equity of the Muslim and Hindu populations coexisting within India.

Abortion is not forbidden to Hindu women, but the women are denied sexual rights and emotional freedom insofar as husbands and their natal kin control most, if not all, aspects of their lives. Such forms of control constitute human rights abuse. For Hindu women, the human rights abuses range in some cases from mobility restrictions to marital rape and forced abortion. These abuses are surmised as just cause for the creation of a progressive uniform civil code. However, such a policy may only be described as "progressive" if a woman's right to exit and dissociate from an illiberal culture is respected regardless of religious affiliation. This means that India has to repeal the Muslim Personal Law (MPL) before it can begin to improve the status of all women in India, not just that of those in the majority. The consequences of the MPL will be detailed in turn. First, the rationale for the investigation into the status of Muslim and Hindu women must be clarified.

\section{Theoretical Rationale}

India was selected for this research because it is unique. It is both multicultural and democratic, while also highly oppressive in its treatment of women. Furthermore, in contrast to the separation of church and state common in the global North, India's federal government has enshrined the personal law of Muslims into federal policy. Followers of Islam are effectively exempted from India's civil law and instead allowed sovereignty over their own civil matters. Consequently, India's version of a multicultural society resembles Kukathas's (2001) libertarian model more closely than Okin's (1998) since the state does not overturn the gendered practices of the Muslim cultural minority when the wider society finds those practices abhorrent.

However, before proceeding in a comparison of women's status within India's two dominant cultures, it is necessary to ground my conceptions of gender and culture, along with feminism, in the context of Indian society. Societies and cultures are always biased toward one sex, while societal cultures, according to Kymlicka (1995), are always biased toward the majority culture. In most cases, societies, cultures, and societal cultures are patriarchal, attributing higher value to the male sex and masculinity in general. This means that women in the minority experience a double discrimination because of their identity as a woman and cultural minority. Many cultures in India-both minority and majority-are deeply patriarchal and remain stratified by gender insofar as women are exclusively defined by their sexed bodies.

\footnotetext{
${ }^{2}$ Kukathas (2001) argues from a libertarian standpoint that the state should tolerate all cultures, whether liberal or otherwise.

${ }^{3}$ Okin (1998) grants primacy to the values of liberal feminism over those of multiculturalism.
} 
Sex determines gendered social roles; subsequently, female genitalia translate into obligatory caregiving and culture bearing duties (Banerjee, 2005).

Additionally, if a woman is part of a minority culture, she will undoubtedly have restrictions placed on her body by dominant males within the group. Patriarchal control of women's bodies is a strategy that minority cultures employ to preserve their distinct cultural identity when they are situated within a societal culture biased toward the majority cultures (Shachar, 2001). Internal restrictions are placed on women's bodies to control group membership because women control the entry and socialization of new members through childbirth and childcare. Consequently, the social norms of a culture often act as structural barriers that constrain women within the private sphere and perpetuate their oppression, thereby preventing their emancipation from male control. These structural barriers are borne of the historical separation of the public and private spheres and the three hundred years of British colonial rule that consolidated patriarchy and communalism in India (Banerjee, 2005).

India's colonial rulers brought with them the Eurocentric conceptions of masculinity and femininity that were less pervasive in Indian society at that time (Banerjee, 2005). The West's understandings of gender roles came to be internalized by India's indigenous peoples who subsequently adopted the colonizers' views of women in India as the "dependent subjects" of husbands, families, and communities. Recognition bestowed on women in India by the British colonial authorities came to reflect the "cult of domesticity" common to colonies controlled by the British Empire. The Warren Hastings Plan of 1772 officially placed women under the dominion of husbands, families, and communities (Mullally, 2004). British colonial legislation divided the public and private spheres, placing matters of inheritance, marriage, caste, and other religious usages and institutions under the authority of religious doctrine and, consequently, the men who interpret it (Mullally, 2004).

In its positioning of private sphere disputes under the control of dominant males, the Warren Hastings Plan de-facto placed women under the exclusive control of men. Personal laws came to define Hindu and Muslim women as the "boundary markers" (Mullally, 2004, p. 676; Steans, 2010, p. 84) of their cultures and traditional practices-now relegated to the private sphere. The British may have perceived Indian men as their effeminate counterparts, but patriarchy dictates that they still recognize women as a man's subsidiary. Furthermore, colonial rule threatened the identities of India's conquered indigenous peoples as it feminized the men (Banerjee, 2005). Colonial feminization fueled misogyny and a hyper-masculine backlash in India where the imported gender norms thrived. This exploration of the historical and social background, against which Indian women have been subjugated, contributes to the apprehension of the cultural and gender barriers that continue to inhibit women's emancipation in India today. 


\section{Women's Autonomy}

Women cannot gain political influence until they have control over their own bodies. And for the purposes of this research, it is unfortunate that there are only scattered data concerning the relationship between religion and reproductive autonomy amidst the literature reviewed. What is known, according to Rahman and Rao (2004), is that purdah and gunghat - the practice of female seclusion where, in certain Muslim and Hindu societies, women are screened from men or strangers - are most prevalent in India's Muslim families. Purdah and gunghat show mixed effects on mobility in that Muslim women require permission to visit friends and relatives but less often require it to visit the market or health center (Rahman \& Rao, 2004). These findings are counter-intuitive to the goals of seclusion insofar as allowing women to run errands without permission or escort creates a larger potential for rape or female infidelity; there are no relatives or friends present to protect or bear witness to extramarital affairs, be they consensual or not. One can only speculate that the logic behind allowing Muslim women to attend only to errands that are ultimately linked to the nourishment and general health of children (without permission) is a product of religious belief. According to P. Saikia (personal communication, October 11, 2010), most Muslim societies maintain the devout belief that children are a gift from God that must be protected even before birth. Consequently, women, as primary caregivers, are allotted some flexibility in their seclusion when it affects the health of children.

Evidence from multiple qualitative studies points to the equal autonomy of Muslim and Hindu women which manifests in different areas of their lives (Rahman \& Rao, 2004). Muslim women consistently have more autonomy within the household, and their influence over household expenditures provides them with a better selection of health care providers than is available to many Hindu women (Rahman \& Rao, 2004). Hindu women have less influence over decisions concerning their own health as husbands and the natal kin of husbands often put financial concerns above the health of a new bride. The availability of finances independent of the husband, however, is the primary indicator of a women's ability to seek maternal health services, according to Bloom, Wypij, and das Gupta (2001). Their study was conducted in an urban district of Varanasi, Uttar Pradesh in northern India, and their findings suggest that employment outside the home as well as contact with natal kin correlates positively with utilization of maternal health services (Bloom, Wypij, \& das Gupta, 2001). This means that when government services are inadequate-they usually are-women seek private health care. Unfortunately, the strict control over finances within extended households, which are common to northern societies, requires women to seek funds elsewhere until they reach an age where their opinions are more influential.

Rahmen and Rao (2004) attribute differences in Muslim and Hindu female autonomy to economic conditions, specifically agriculture. They argue that when women work outside the home, their contributions to the household budget are acknowledged and they are afforded 
greater input in financial matters (such as using money earned to pay for abortions, safe or unsafe). In southern India, women contribute more because the economy is largely dependent on wet-rice cultivation-women are said to have a comparative advantage in this vocation, although Rahmen and Rao do not elaborate on what this advantage is. The North contrasts the South in that crops are primarily wheat, which is easier for men to harvest because biology dictates that, on average, men typically posses greater upper-body strength than women do. Consequently, women's lack of authority in the North can be traced to their lower contribution to the household budget.

Lower financial contributions do not, however, always correlate to lower labour contributions. The embodied labour women perform as part of their primary caregiving responsibilities (housework and child-rearing) is not given monetary value and thus not taken into account as a contribution to the household budget (Salleh, 2009). Moreover, with fewer options to participate in the labour force, women in the North have to rely on the patriarch as the sole monetary provider. This argument, put forth by Rahmen and Rao (2004), is limited in that it can only apply to Hindu women because Muslim women are less likely to work in agriculture (Jejeebhoy \& Sathar, 2001). Therefore, the greater control Muslim women have over finances cannot be attributed to crop variety. Rahmen and Rao's work could benefit from a broader claim that encompasses the sales work in which Muslim women are more commonly engaged as it is a form of wage labour that is recognized as a contribution to the household budget.

The influence Muslim women hold over finances can mean the difference between life and a pregnancy-related death. India's maternal health services vary tremendously by region because of the inequitable development and distribution of resources that plague the country. Maternal health service providers in India include state-run facilities, certified (or uncertified) private doctors, midwives, and traditional delivery services. Having some control over the household budget allows Muslim women to choose the safest option available to the family. Young, low-caste Hindu women are not as fortunate. If the kinship model is exogamic-spouses are unrelated and originate from different birthplaces and areas of residence, a Hindu woman will be subject to the authority of the husband's family, who will often opt for the lower costing, less safe, traditional delivery within the home (Vissandjée, Barlow, \& Fraser, 1997). Hindus in general have been found to have a higher maternal mortality rate (573 per 100,000 live births) than Muslims (384). Muslims also fared better than Hindus in terms of infant mortality rate. For Hindus, it stands at seventy-seven per thousand, much higher than Muslims (fifty-nine per 1,000) (Registrar General, India, 2006).

\section{Kinship and Geopolitics}

According to Dyson and Moore (1983), India's kinship models have the greatest impact on women's autonomy. They characterize kinship models by three key principles: marriage rules, 
ties to natal kin, and property rights. Marriage rules largely define the institution of marriage in India. Depending on the primacy of female chastity and dowry (property or money brought by a bride to her husband on their marriage), marriage may be a strictly financial ritual as well as a means for establishing alliances between families rather than a celebration of love. Ties to natal kin are especially important for women because without them, new brides can be left without any financial, social, or emotional support. The husband's family can be hostile to the new bride if her dowry was not significant enough or if she bears female children, as son preference is very common in patriarchal cultures in South Asia (Seager, 2009). Property rights, if they are recognized, are also a valuable resource for women in India. For widows or female siblings, having ownership rights to property can serve as a protection against debt bondage because the land can be farmed, sold, leased, or used to leverage loans. In other words, property rights translate into independent income for women in India. Different combinations of these kinship practices determine the autonomy of women in different regions of India.

The major differences in gender equality between the North and South arise from these three principles of kinship (Dyson \& Moore, 1983). In the North, marriage rules are exogamic, leading to great tensions between patrilineally related groups of males. Marriage becomes the means of establishing alliances between groups. The chastity of wives is of great importance and can often lead to purdah and gunghat (Rahman \& Rao, 2004). It is also not uncommon to find dowry concerns provided by a new bride's in-laws as a cultural defense ${ }^{4}$ for sati, a form of femicide where a new bride is burned at the stake (Kumar \& Kanth, 2004). The cultural accommodation legal defense is addressed in the section discussing MPL. When sati occurs, it is labeled culturally from a defensive stance as an "honour killing." ${ }^{5}$ In fact, the murder is used as a means for the husband to renege on marital vows without returning the dowry. Furthermore, in some northern states, the emotional ties between husband and wife are thought to threaten group solidarity, causing women to be separated from the men and the political aspects of the marriage arrangement. Wives, and women in general, are stereotyped and (mis)recognized as selfish, malicious, and promiscuous; they are said to corrupt men's logic and reason with their destructive mannerisms (Dyson \& Moore, 1983). The importance of dowry and chastity, in addition to the disingenuous concerns for an emotive connection between spouses, transforms the ceremony of marriage under the northern kinship model into a formalized and state sanctioned trafficking in human beings (Sullivan, 2010).

A representative example of the impassive nature of northern marriage rules is the offering of dowry combined with the fact that women are rarely allowed to visit their natal kin after marriage. New brides are thought to begin a completely new life after marriage so that

\footnotetext{
${ }^{4}$ The cultural defense argues that "[p]ersons socialized in a minority or foreign culture, who regularly conduct themselves in accordance with their own culture's norms, should not be held fully accountable to the full prescriptions of their own culture" (Magnarella, 1991, p. 67).

${ }^{5}$ The term "honour killing," much like "mail order bride," is contested because it takes away women's agency and removes any context or backstory from the motivation for why the murder occurred.
} 
the interests of the bride's natal kin do not threaten those of the husband's family (Bloom et al., 2001). The social life of a Hindu woman in the North is considerably gendered, given the importance of a woman's chastity, dowry, and her lacking contact with natal kin. She also holds no property or inheritance rights, making her merely the link through which property rights are transferred to offspring. Northern kinship practices severely restrict women's autonomy. Brides are seen only as sexual objects and empty vessels whose purpose in life is to birth (preferably) male children and serve men. The northern kinship model places them under the control of men and the mothers of those men, thereby denying them any agency whatsoever.

Employment opportunities are also gendered in the North insofar as women residing in northern states are commonly limited to formal employment in which they may only interact with other women. This ensures their chastity and the group's solidarity while also reinforcing traditional gender roles, since women primarily become teachers and nurses if they are not participating in agricultural labour. Under this repressive model of kinship, a woman's only means of exercising any social influence as a new bride is through gossip and other such social channels (Dyson \& Moore, 1983). Brides are most often subjected to the authority of their mother-in-law because northern families tend to live in extended households where multiple generations cohabit (Vissandjée et al., 1997). However, all of the authors within the literature reviewed agree that with increased age comes increased autonomy, regardless of region (Dyson \& Moore, 1983; Bloom et al., 2001). Trust and influence are gained incrementally.

\section{Access to Maternal Health Care Services}

Though the kinship model greatly influences a woman's autonomy and access to maternal health services, the region in which she resides often determines the quality of service. Health care is a state head-of-power in India, and states are allowed to tailor their health services to the needs of each community. In many countries, this model is highly efficient, as lower levels of government are often more sensitive to the needs of their constituents than the federal government. Unfortunately, the political and bureaucratic corruption in India leads to large disparities in the provision and quality of health care. Rural areas are dominated by private clinics because the government facilities are of poor quality and lack the staff needed to meet demand (Bhatia \& Cleland, 1995). Government services may be advertised as free, but patients often have to incur hidden expenses, creating the perception that there is no real advantage in using government services. Private practitioners fill the gap by providing services ranging from family planning services to antenatal and postnatal care. However, these services are expensive, and most women cannot afford them. They can also be risky, as most practitioners have no certified medical qualifications (Bhatia \& Cleland, 1995).

In the conservative northern states, health care is largely provided by poorly regulated private enterprises offering mostly substandard services (Chawla, 2007), though they are still desirable relative to those provided by the state. The inadequate provision and scarce use of 
maternal health services contributes to a high rate of maternal mortality: 599 deaths per 100,000 live births in Uttar Pradesh compared with India's total average of 437 deaths per 100,000 live births (Bloom et al., 2001). Preference for male children is high because of the traditions of patrilineal decent, producing sex ratios in Rajasthan of 850 females per 1,000 males (Seager, 2009; Chawla, 2007). It appears that capitalist pressures and patriarchy reinforce son preference and the feminization of poverty in northern India. Male children are perceived as economic assets insofar as they can generate future income for the family, in contrast to daughters, whom are perceived as economic burdens (Chawla, 2007).

Despite region and kinship model's effect on women's maternal health, class remains the foremost indicator of a woman's access to maternal health services in rural India, according to Vissandjée et al. (1997). Vissandjée et al. demonstrate how the travel variable is the largest impediment to women's access to maternal health services because of hidden costs associated with travel-time off from work, transportation, food, accommodation, and so on. Older highcaste Hindu women fare best because they control enough resources to have a private doctor come to their home. Contrary to the privileged upper-caste, low-caste Hindu women are faced with barriers to their own human security as they struggle to find time off from agricultural work to travel to a clinic (Vissandjée et al., 1997). Young low-caste Hindu women living in extended family households are particularly susceptible to maternal mortality. The mother-inlaw's influence over family finances often means the pregnant daughter-in-law will be more likely to have a less safe traditional childbirth which is cheaper than a physician-assisted birth (Vissandjée et al., 1997). In contrast, Muslim women are less alienated from natal kin than northern Hindu women, that familial contact can mean better health care for a woman because natal kin will often assist in financing a safer in-hospital birth (Jejeebhoy \& Sathar, 2001). A woman's access to maternal health care depends on numerous variables including caste, class, age, religion, location, kinship practices, and community norms and mores.

In southern India, the ideal marriage in both Muslim and Hindu cultures is between second cousins or between uncle and niece. Marriage rules are endogamic, meaning that brides live closer to their natal kin and are thus likely to visit more often. Closer ties to natal kin provide married women with more financial resources with which to exert influence over their reproductive autonomy. Women's sexuality and movement are less strictly controlled, and, therefore, female chastity is of less importance in the South. Evidently, marriage is less politically gendered and more egalitarian under southern kinship models insofar as the union is based on mutual attraction between partners rather than financial benefit. In the more egalitarian South, kinship practices dictate that women can sometimes inherit property rights, as marriage ties are as important to social organization as blood ties. Marriage arrangements are more conventional, considering that dowry is less prevalent and nuclear families are more common with the ties between husband and wife not perceived as a threat to the social group. This allows for less sex-specific communication and therefore less restriction on a women's 
choice of employment (Dyson \& Moore, 1983). The greater autonomy of women in South, relative to those in the North, must be attributed to the kinship practices inherited from the Dravidian culture insofar as Muslim and Hindu women's freedoms vary only in minor instances such as employment.

In contrast with the northern states, southern states, such as Tamil Nadu, are more developed and have a more modern liberal culture. Income is much higher, the human development index is higher, fertility rates are lower, son preference is less prevalent, and the government and bureaucracy are much less corrupt (Chawla, 2007; Seager, 2009). The government in Tamil Nadu also invests more in public health care; it owns 78 percent of the hospitals (Chawla, 2007). However, in India, the federal government does not make equalization payments to its "have-not" states as the Canadian government does to the provinces. Consequently, resources are concentrated in various regions of the country, as opposed to being distributed equally, causing women in many rural districts to seek privatized abortion service providers (many of whom are without any recognized medical qualification) because of the greater accessibility and quality relative to that of government service providers (Varkey et al., 2000).

Seeing as abortion is more acceptable within the southern Hindu culture, the South can be thought more liberal in terms of reproductive justice than the North. The intense aversion to abortion in the North may be attributed to the influence of the husband's family's often traditional values, which are common in the extended households of the northern Aryan kinship model (Dyson \& Moore, 1983). The comparative wealth and modernization common in the South correlate with modern liberal values, which allow women greater access to maternal health services. The inequitable distribution of resources within those states, however, leaves many rural pockets of poverty in which women's maternal health occupies a disadvantaged position. Southern culture may provide women with a greater reproductive autonomy, but when an impoverished woman must journey great distances to exercise this freedom, the travel variable proves more important than either region or religion.

\section{Religion and Reproductive Rights}

Amongst all the analysis of culture, kinship structures, and regional disparities, there lie only scattered data concerning the religious aspect of culture and reproductive autonomy. The data suggest that Muslim women are no less autonomous than Hindu women in terms of their access to maternal health services (Bloom et al., 2001; Jejeebhoy \& Sathar, 2001; Rahman \& Rao, 2004). Muslim women consistently have more decision-making power within the household as well as on issues concerning of their own health and that of their children (with the exception of accessing abortion services) (Rahman \& Rao, 2004). The greater influence Muslim women hold in these areas can be attributed to their responsibilities as the primary caregivers. The Muslim male vanguard interprets the Koran in a manner that strictly restricts 
women's reproductive agency. Aside from these restrictions, Muslim women are largely autonomous within the domestic sphere. Hindu women differ insofar as they are more reproductively autonomous but wield less influence in household decision-making.

Muslim women may have a greater ability to reach clinics for prenatal and antenatal services, but the use of any form of birth control is forbidden by Muslim religious doctrine (Chawla, 2007). Consequently, the fertility rate among Muslim women is higher (Jejeebhoy \& Sathar, 2001) relative to Hindu women, whose rates of maternal mortality are climbing because of unsafe abortion (Seager, 2009; Varkey et al., 2000). More children translate into greater responsibilities for women as the primary caregivers, causing a decrease in the likelihood of their becoming politically active. Contraception may be forbidden to protect unborn Muslim children, but it effectively limits a woman's control over her body and life choices.

At the other end of the spectrum, abortion has become normalized within Hindu culture. Many Hindu women believe that it is normal to have at least one abortion in a lifetime (Varkey et al., 2000); they use it as a means of spacing out births and limiting family size. Rather than using temporary contraceptive measures such as condoms or IUDs, 49 percent of Hindu women opt for their own sterilization while only 0.3 percent of Hindu men get sterilized (Sundari Ravindran \& Balasubramanian, 2004). Hindu women are said to not use condoms for three reasons: (1) they reduce the man's pleasure during intercourse; (2) they are not regularly available; and ( 3 ) they are difficult to dispose of, as men often prefer to flush them down the toilet, raising both plumbing and environmental issues. Furthermore, many Hindu women consider condoms to be appropriate only for prostitutes and extra-marital relationships and when a man fears he will get HIV. They may be forced by their families to have abortions in some cases (Sundari Ravindran \& Balasubramanian, 2004). Reasons offered by Hindu women for their distaste for IUDs and birth control pills are complaints of adverse side effects and the inconvenience of having to take the pill daily (Sundari Ravindran \& Balasubramanian, 2004; Varkey et al., 2000). It appears that India's patriarchal culture creates a distaste in both Hindu and Muslim communities for contraceptives. These attitudes toward birth control and women's bodies reflect the gendering of Indian society that socializes women to internalize feelings of inferiority, leaving their bodies vulnerable to male control. They reflect the low status Hindu women carry within their marriages and society in general.

As Sundari Ravindran and Balasubramania (2004) demonstrate, Hindu culture has effectively said "Yes" to abortion but "No" to women's sexual rights. In some cases, this repression translates into the husband's all-encompassing control over his wife's body, posing a threat to her human security. When a woman's human security is threatened under such circumstances, Okin (1998) would argue, India, as a liberal democracy (according to Freedom House (2010)), has a positive obligation to reform the cultural practices of the oppressor group. Her claim that groups whose traditions and practices are illiberal should be reformed through education preferably, but where necessary by punishment, is important (Okin, 1998). India, 
however, is unable to take any policy advice from Okin because (a) Okin ignores the possibility that illiberal traditions may have real and valuable meaning for the women whom she assumes are oppressed and trapped in a false consciousness and (b) the corruption and instability of government renders the implementation of such progressive national reforms impossible. Though it is true that some cultures socialize one sex (usually the female) into inferior roles, Okin's argument assumes that all women who do not value liberal feminism have a false consciousness. Perhaps her framing of a dichotomy between culture and feminism is essentialist in its approach insofar as it forces individual women to choose one at the expense of the other. Often, the perceived choice is only an illusion, as culture is a major aspect of identity. When culture is lost, an individual may also lose his or her family, friends, social support, and financial support. Indeed, there is much to lose if a woman chooses rights over culture.

\section{Policy Recommendations - Family Planning}

In a country where abortion has been legal since 1971, women should not be opting for sterilization and unsafe abortion in such large numbers. They are only doing so because they cannot force vasectomies on their male sexual partners. Furthermore, safe abortions in India are too costly while cheap abortions are unsafe-especially when preformed by an unqualified practitioner using high-risk procedures as late as seven months into a pregnancy (Seager, 2009; Varkey et al., 2000). The federal government should be combating India's distaste for temporary contraceptive use because this will reduce the spread of HIV-which in South and South-East Asia is the highest after Africa (Seager, 2009)-and it will help control the growth of a population which India cannot sustain even at present. Fortunately, the federal government can at least take a step in the right direction without implementing any major policy reforms. It could invest heavily in sex education and promotion of condom use to promote safe sex and to dispel the stigma attached to condom usage. Condoms are not simply an implement created for sex workers or unfaithful husbands; they are a weapon that the state should draw to combat both the spread of HIV to men and women and India's unsustainable population growth (Central Intelligence Agency, 2010). The medical services required for childbirth and HIV treatment are expensive and cost India large sums of money. This is money that could be redirected toward its development goals. Proactive policies would greatly reduce percentage of the state's budget that is dedicated to health care (World Health Organization, 2006). India's family planning programs need intensive reforms, and the proactive prevention of pregnancy is consistent with both India's economic interests and its human rights concerns. Disease prevention and population decline should reduce medical expenditures as increased condom usage allows women at least some control over their bodies. 


\section{Sexualized Violence - Hindu Women}

Many women have some ability to control their fertility in the South, but not enough as to be able to generalize beyond Jejeebhoy and Sathar's (2001) findings that fertility rates for both Muslims and Hindus are lower in the South than in the North. Though southern women are said to have greater autonomy due to a more egalitarian culture, Hindu women residing within the progressive state of Tamil Nadu are commonly victims of sexual violence within their marriages. I speculate that the same is likely true for Muslim women. Nonetheless, the disturbing quotations of Hindus in Ravindran Sundari and Balasubramanian's (2004) research on abortion in the South of India illustrate experiences with marital rape and domestic violence, instead of supporting claims of a relatively egalitarian society. They report the following:

Sixty percent of the women interviewed (44/66) stated that they could not refuse if their husbands desired to have sex. Sexual violence was embedded within marriage in a wider context of the use or threat of physical violence to keep women submissive, however. Five women reported intimate partner violence if a non-sexual nature in addition to the 40 who reported sexual violence. (Ravindran Sundari and Balasubramanian, 2004, p. 95)

Hindu men are "taking abortion very lightly in India - as if it were something they can pay for and be done with" (Ravindran Sundari \& Balasubramanian's, 2004, p. 98). As a result, many Hindu women are having abortions because they lack the ability to say no to their husbands. This lack of sexual agency leaves them disempowered and oppressed.

Forced abortion and marital rape are intimately connected and threaten a woman's human security. Moreover, they are not matters that can be brushed aside by claims of cultural relativism. According to the Universal Declaration of Human Rights, Article 3, "[e]veryone has the right to life, liberty[,] and security of person." Consequently, women (no matter what their identity or marital status) have the right to be sovereign over their own bodies, and they have the right to say "No" to sex. This is not the case according to several of the Hindu women interviewed in Ravindran Sundari and Balasubramanian's (2004) research. The atrocious sexualized violence discovered in their study can only be communicated satisfactorily by quotation. In these instances, the wives are defined exclusively by their bodies and misrecognized by husbands as sex slaves and empty vessels. The women have no visible agency; they appear to be objectified and recognized as the private property of men. Some men might regret their cruelty in the morning; however, they will only commit to financing abortions as a solution to the unwanted pregnancy resulting from their sexual abuse.

Some young Hindu women have described their sexual experiences with men as well as their personal views on abortion:

I have aborted two pregnancies - the second and the fourth. Fear and embarrassment in asking for spacing methods and his compulsion for sex have led to three unwanted pregnancies and two abortions. Even though men are 
responsible for pregnancy, people generally say it is the woman's fault. They say:

"Men are good, but women are foolish, emotional and looking for bodily pleasure." (Ravindran Sundari \& Balasubramanian, 2004, p. 96)

Here is a young woman whose culture is highly conservative, making sex a topic not often available for discussion. Fear and embarrassment should not serve as a justification to abstaining from a serious discussion concerning birth control. Moreover, the stereotype that women are foolish and irrational serves only as an outdated sexist tool with which to repress women. In India, the man always claims to know the best course of action. Sex, for the men discussed in this study, is not a reciprocal expression of love between partners but rather a mechanical performance choreographed for men's exclusive pleasure. A woman has little say even when her life is in jeopardy:

I am pregnant now. I had decided to abort this one also, whether I live or not (my emphasis). But he and my father convinced me to have this child and then have the operation. [After the previous abortion,] the doctors did not say anything about preventative methods [contraceptives]. When I asked my husband to find out whether there is anything to avoid getting pregnant, he said:

"Am I having sex with a prostitute that I have to ask about preventing pregnancy?" (Ravindran Sundari \& Balasubramanian, 2004, p. 96)

Ravindran Sundari and Balasubramanian's study accurately paints a shameful portrait of patriarchy and misogyny in the lower-castes of Hindu society.

The study participants (93 percent belonging to the low-caste dalit community) represent the largest caste in the Hindu caste system, making the dalit-dominated sample an accurate, while disturbing, portrayal of marital relations in Hindu culture. It reveals the painfully low status Hindu women have in a culture that socializes them to believe that they are, for all intents and purposes, the property of the patriarch, be it a father or husband. Many Hindu men see sex within marriage as a right in which a Hindu wife has no say. They do communicate an understanding that the sexualized violence they inflict upon their wives is wrong, although they also convey that they will continue to assert their dominance as long as their actions continue to lack consequence. Such misogyny is not limited to Hindu culture, as it is part of the legacy of British colonialism where the colonizers feminized the indigenous peoples in India. Muslim women are in a position no less oppressed because, without access to birth control, they are forced to have more children than they have the means to provide for (Census of India, 2001; Jeffery and Jeffery, 1997; The Council on Foreign Relations, 2007). Poverty compounded with a high birthrate causes the legitimization of birth control to sit high on the agenda of Muslim women's rights activists (or Islamic feminists).

\section{Women's Rights Activism}

Islamic feminists cannot appeal to the state to lend legitimacy to their claims as Hindu women 
may. Muslim women's claims to freedom and equality are complicated by the MPL, which requires the state to remain largely neutral on matters of cultural practice. The MPL serves as both a restriction and lifeline to Islamic feminists because it calls for the resolution of private sphere disputes as prescribed by religious doctrine derived from the Koran. Historically, men have been the sole interpreters of the Koran, and while traditionally religious texts have been read patriarchally, a new breed of Islamic feminists have argued that the Koran "grants Muslim women numerous rights that in practice are routinely denied" (Vatuk, 2008, p. 489). These women seek to change Islam from within by reinterpreting the Koran with a gender-neutral understanding rather than lobbying a federal government for a uniform civil code that does not serve its own electoral interests.

The fact that the state has no role to play in the Muslim private sphere can also be recognized as an advantage for Islamic feminists. Once their social movement to reform MPL reaches a critical mass, change can be made swiftly without too many formalities and bureaucratic red tape. If Islamic feminists could pursue litigation strategies or other conventional modes of pursuing social change, they would be faced with corruption and partisan barriers in addition to sexism. Instead, by choosing to derive their values from feminist interpretations of the Koran, Islamic feminists are reclaiming their religion by challenging the well-entrenched and widely influential religious authorities in Muslim culture. Their challenges are supported by the educational and technological advances associated with globalization which have allowed for religious texts to be mass produced and read by more people who no longer have to rely on middlemen to (mis)interpret the word of Allah.

This surfacing fragmentation within the Muslim community indicates a problem that must be addressed before the outdated gendered traditions can be overhauled. A Muslim woman is twice marginalized within India because she belongs to a minority religion whose traditions and practices are highly gendered. The dominant voices claiming to represent the interests of all Muslims in India are but a small elite fraction of men within the culture. These men privilege themselves and men in general by silencing subversive voices of feminists within the group who are calling for the promotion of women's rights within an Islamic framework. The male elite has exclusive control over the interpretation of the Koran's text. They employ this power to dispel dissenting groups, such as the Sisters of Islam, by deploying accusations of the Sisters' acquiescence of western values and Americanization. Listening to these rebellious women will benefit Muslims as a group in terms of both health and human security (Obaid, 2005).

Large families are commonly unsustainable in developed nations, let alone densely populated developing ones such as India. The reality facing Islamic culture is that Allah is not providing for all and leaving the size of a family up to His will is irresponsible. Contraception may seem unacceptable to the majority of Muslims today, but if the leaders of Muslim organizations are invited to and involved in India's family planning programs, perhaps these 
perceptions will change. What I am calling for is a globalization of feminist values from below. Grassroots organizations like Development Alternatives for Women Network (DAWN) need to be included in the discussion on state policy. DAWN and its sister organizations bring the lived experiences of women and other actors, whom the decisions of the state affect most, to the policy table (Moghadam, 2005). Obaid (2005) illustrates the feasibility of such measures by identifying five stages adopted in Indonesia to involve Muslim leaders in a national family planning initiative:

1. Learning and understanding their roles and status among the people;

2. Building the vision that Islam is not against family planning and reproductive health;

3. Continuing communication with Muslim leaders and organization for their advice and religious interpretation;

4. Providing non-financial rewards for the involvement of Muslim leaders and organizations; and

5. Supporting programs in reproductive health and family planning by these institutions. (p. 1167)

The Sisters of Islam and the Indonesian example of government collaboration with faith-based institutions demonstrate that the Muslim culture is not monolithic. There are dissenting factions within the groups, and there are leaders open to the adjustment of certain religious laws to end the unnecessary suffering attributed to HIV and unwanted pregnancies.

\section{Muslim Personal Law and the Shah Bano Case}

The key difference between Muslim and Hindu women in their pursuit of human rights is that their cultural identity impacts both to whom they address their claims for gender justice and how they present those claims. Hindu women are better situated under federal legislation to exit from abusive marriages because their cultural group is the majority and therefore the largely Hindu societal culture is more receptive to their claims. Muslim women, however, as part of a minority group, face cultural barriers that inhibit the state's accommodation of their human rights. In the Shah Bano case, a Muslim woman invoked the Code of Criminal Procedure-a general law applying to all citizens regardless of religion -in her efforts to exit the confines of MPL (Mullally, 2004). She was seeking maintenance (alimony) from her former husband, who retorted that his duty to pay should be determined under the Muslim Personal Law and not the general law (Mullally, 2004). The Supreme Court ruled for Shah Bano, providing the federal government with a convenient opportunity to implement a uniform civil code. In fact, the Court explicitly called on the Government to do so (Mullally, 2004). Unfortunately, conservative Muslim elites responded by influencing Shah Bano's community to pressure her to withdraw her claim for maintenance. They drew on essentialist representations of Muslim culture to influence the government to support their interests because any perceived 
disregard toward Muslims could result in the administration's loss of the Muslim voter support it needed to maintain rule. Subsequently, the federal government enacted the 1986 Muslim Women's (Protection of Rights in Divorce) Act and effectively overturned the Court's verdict. Government responsiveness to communal interest group pressure has reinstated the ties that bind Muslim women to their husbands, families, and communities as dependent subjects and boundary markers. Shah Bano's coerced recantation homogenized the Muslim culture in India, creating the illusion of group solidarity thereby successfully denying Muslim women the right to participate in debates to determine the limits of cultural claims.

The Shah Bano case illustrates the debates surrounding the way in which claims for multicultural accommodation are used to silence women. Culture is too often taken as an inalienable monolith, causing the dissent within the religious community to be ignored (Mullally, 2004). Moreover, India's discourse of communalism defines individuals solely through religious membership, thereby sacrificing gender equity to placate communal tensions (Mullally, 2004). Under pressure from her community, Shah Bano had no choice but to recant her claims because she would have been ostracized. Court-ordered maintenance would also have been difficult for her to enforce from her marginalized position. She would be forced to uproot her life and relocate, starting alone in a new community and lacking the social or financial resources necessary to provide for herself.

The combination of communalist discourse and the election of weak coalition governments result in the preserved legitimacy of a gendered personal law for Muslims, which restricts a woman's ability to exit and dissociate herself from the confines of Islam. According to both Mullally (2004) and Okin (1998), great numbers of Muslim women do not support the illiberal status quo. Many Muslim women in India do not support the patriarchal practices that leave them subservient within their culture. Mullally demonstrates how they "have protested the double standard that is being applied on behalf of their aggressors" (p. 674) with legal cases studies while Okin does so with interviews. Unfortunately, the federal government is hesitant to override the personal laws of religion because of their liberal multicultural discourse, which states that all cultures must be respected, even the illiberal ones which the wider majority finds abhorrent. India has even ratified the 1979 UN Convention on the Elimination of All Forms of Discrimination Against Women which has been critical to the raising of awareness regarding violence against women around the globe (Joachim, 2007), but it did so only upon the inclusion of a caveat declaration stating that the convention cannot interfere with the personal laws of minority communities (Mullally, 2004).

The MPL refuses Muslim women the rights entitled to them by virtue of their humanity and citizenship. The defense of cultural differences fails to justify the oppression of Muslim women. MPL exposes India's commitments, both international and domestic, to women's human rights as empty promises. The Supreme Court of India would agree that the rights of individuals should be held above the interests of groups in a liberal democracy because the 
intended ruling favoured Shah Bano's individual rights over the MPL's "distinct culture" defense. Groups are not important in and of themselves; their worth lies only in the importance they hold for the individual's well-being. If a group's traditions impair the well-being of one gender to advance the interests of another, those practices should be redressed by the state. Hindu women are better equipped with more legal rights and state assistance to distance themselves from the illiberal traditions that constrain them because the state interprets the law. These tools are unavailable to Muslim women, who must conform to the demands of religious elites who interpret the Koran and MPL.

The Shah Bano case provides a definitive example of how important it is that the federal government implements a progressive uniform civil code to better protect both Muslim and Hindu women from the paradox of multicultural vulnerability. Cultural restrictions should not be placed on women's bodies solely in the interest of protecting a group's distinct cultural identity. Hindu women do have more resources and autonomy to pursue rights claims than Muslim women under some circumstances, but the reverse is also true. None of this is to say that Muslim women should not continue with reclaiming their religion. By continuing their struggle and networking with other feminists, Muslim women can nationalize their pursuit of substantive reproductive and gender justice in India.

\section{Conclusion}

Hindu women have the law on their side while Muslim women are faced with a male dominated theocracy. This dynamic, however, can work in favour of Muslim women. Islamic feminists can mobilize their Muslim sisters to displace the men who exclude them and their interpretations of the Koran. One may also appeal to the state to put aside the partisan politics and get to work, as India's multiculturalism is essentializing and prioritizing culture at the expense of a culture's weakest group members, namely women and children. Unfortunately, the leadership gap limits the legislature's ability to pass any bills other than those that reflect regional and political favouritism. The Indian government's legislative inabilities leave the pursuit of gender and reproductive justice in the already full hands of women and civil society. Hindu and Muslim women must work together in concert to emancipate themselves from the cultures which render them the powerless objects of men. They must form a coalition of their own within Indian civil society focused on conscious-raising and social support to resolve communalist and gender tensions in India. Much of this progress is currently underway as India's women struggle to come together in solidarity through coalition. The voices of feminism in contemporary India are growing in volume as they untie the tipping point of equal rights legislation approaches. It is very likely that the grassroots organizations and research by women in civil society and NGO's will have to be the drivers behind the social change needed to gain reproductive justice for both Hindu and Muslim women. 


\section{References}

Banerjee, S. (2005). Make me a man! Masculinity, Hinduism, and nationalism in India. Albany: State University of New York Press.

Bhatia, J. C., \& Cleland, J. (1995). Determinants of maternal care in a region of South India. Health Transition Review, 5, 127-142. Retrieved from http://www.jstor.org/

Bloom, S. S., Wypij, D., \& das Gupta M. (2001). Dimensions of women's autonomy and the influence on maternal health care utilization in a North India city. Demography, 38(1), 67-78. Retrieved from http://www.jstor.org/

Central Intelligence Agency. (2010). The world factbook: India. Retrieved from https://www.cia.gov/library/publications/the-world-factbook/geos/in.html

Chawla, B. (2007). Women's education, health and fertility in India: Examining three states in India: Bihar, Rajasthan and Tamil Nadu. (Unpublished doctoral dissertation). International Comparative Education, Standford University. Retrieved from http://suseice.stanford.edu/monographs/Chawla_Bhawna.pdf

Dyson, T., \& Moore M. (1983). On kinship structure, female autonomy, and demographic behavior in India. Population and Development Review, 9(1), 35-60. Retrieved from http://www.jstor.org/

Freedom House. (2010). Freedom in the world. Retrieved from http://www.freedomhouse.org/template.cfm ?page $=22 \&$ country $=7840 \&$ year $=2010$

Hansen, L. (2010). Ontologies, epistemologies, methodologies." In L. J. Shepard (Ed.), Gender matters in global politics: A feminist introduction to International Relations (pp. 17-28). New York: Routledge.

Hutchings, K. (2010). Ethics. In L. J. Shepard (Ed.), Gender matters in global politics: A feminist introduction to International Relations (pp. 61-73). New York: Routledge.

Jeffery, R., \& Jeffery, P. (1997). Population, gender, and politics. Cambridge University Press.

Jejeebhoy, S. J. \& Sathar, Z. A. (2001). Women's autonomy in India and Pakistan: The influence of religion and region. Population and Development Review, 27(1), 687-712. Retrieved from http://www.jstor.org/

Joachim, J. M. (2007). Agenda setting, the UN, and NGOs: Gender violence and reproductive rights. Washington, D.C.: Georgetown University Press.

Kukathas, C. (2001). Is feminism bad for multiculturalism? Public Affairs Quarterly, 5(2), 83-98. Retrieved from http://www.jstor.org/

Kumar, V., \& Kanth, S. (2004). Bride burning. The Lancet, 364, 18-19. Retrieved from http://www.thelancet.com/

Li, P. (1999). Race and ethnic relations in Canada. $2^{\text {nd }}$ ed. Toronto: Oxford.

Magnarella, P. J. (1991). Justice in a culturally pluralistic society: The cultural defense on trial. Journal of Ethnic Studies, 19, 65-84. 
Moghadam, V. M. (2005). Globalizing women: Transnational feminist networks. London: John Hopkins University Press.

Mullally, S. (2004). Feminism and multicultural dilemmas in India: Revisiting the Shah Bano case. Oxford Journal of Legal Studies, 24(4), 671-692.

Obaid, T. A. (2005). Religion and reproduction health and rights. Journal of the American Academy of Religion, 74(4), 1155-1173. Retrieved from http://jaar.oxfordjournals.org

Okin, S. M. (1998). Feminism and multiculturalism: Some tensions. Ethics, 108, 661-684.

Okin, S. M. (1999). Is multiculturalism bad for women? In J. Cohen, M. Howard, \& M. C. Nussbaum (Eds.), Is multiculturalism bad for women? (pp. 8-24). New Jersey: Princeton University Press.

Rahman, L., \& Rao, V. (2004). The determinants of gender equality in India: Examining Dyson and Moore's thesis with new data. Population and Development Review, 30(2), 239268. Retrieved from http://www.jstor.org/

Salleh, A. (2009). Eco-sufficiency and global justice: Women write political ecology. London: Pluto Press.

Seager, J. (2009). The penguin atlas of women in the world, 2nd ed. New York: Penguin Books. Shachar, A. (2001). Multicultural Jurisdictions: Cultural Differences and Women's Rights. Cambridge, UK: Cambridge University Press.

Steans, J. (2010). Body politics: Human rights in international relations. In L. J. Shepard (Ed.), Gender matters in global politics: A feminist introduction to International Relations (pp. 74-88). New York: Routledge.

Sullivan, B. (2010) Trafficking in human beings. In L. J. Shepard (Ed.), Gender Matters in Global politics: A feminist introduction to International Relations (pp. 89-102). New York: Routledge.

Sundari Ravindran, T. K., \& Balasubramanian, P. (2004). "Yes" to abortion but "no" to sexual rights: The paradoxical reality of married women in rural Tamil Nadu, India. Reproductive Health Matters, 12(23), 88-99. Retrieved from http://www.jstor.org/

United Nations. General Assembly. 1949 Universal declaration of human rights. Retrieved from http://www.un.org/en/documents/udhr/

Varkey, P., Balakrishna, P. P., Prasad, J. H., Abraham, S., \& Josheph A. (2000). The reality of unsafe abortion in a rural community in South India. Reproductive Health Matters, 8(16), 83-91. Retrieved from http://www.jstor.org/

Vatuk, Sylvia. (2008). Islamic feminism in India: Indian Muslim women activists and the reform of Muslim Personal Law. Modern Asian Studies, 42(2), 489-518. Retrieved from http://journals.cambridge.org/

Vissandjée, B., Barlow, R., \& Fraser, D. W. (1997). Utilization of health services among rural women in Gujarat, India. Public Health, 111, 135-148. Retrieved from http://www.jstor.org/ 
World Health Organization. 2006. Country Cooperation Strategy. Retrieved from http://www.who.int/countryfocus/cooperation_strategy/ccsbrief_ind_en.pdf The Council on Foreign Relations. 2007. India's Muslim population. New York: Author.

\section{Contact Information}

Joshua Kepkay, from the Department of Political Science, can be reached at jdkepkay@gmail.com.

\section{Acknowledgements}

I would like to thank the University of Victoria for the opportunity to pursue my own independent research. Also, I would like to extend thanks to my mentor and supervisor, Dr. Janni Aragon, for the guidance, support, and wisdom that she continually provides me and so many other students with. 